\title{
Magnetic Susceptibility Observation Across Himalaya-Karakoram Range, Northern Pakistan
}

\author{
Mirza Naseer Ahmad* and Mitsuo Yoshida** \\ * Geoscience Laboratory, Geological Survey of Pakistan, Islamabad, Pakistan (presently \\ at Division of Earth and Planetary Sciences, Graduate School of Sciences, Hokkaido \\ University, Sapporo 060, Japan, e-mail: naseel@cosmos.sci.hokudai.ac.jp) \\ ** Geoscience Analysis Centre, Geoscience Co.,Ltd., Moto Asakusa 3-13-14, Taito-ku, \\ Tokyo 111-0041, Japan, e-mail: myoshida@geoscience.co.jp
}

\begin{abstract}
Low field magnetic susceptibility was observed for the rocks exposed along Karakoram Highway, northern Pakistan, traversing from Hasan Abdal town, north western margin of Indo-Pakistan subcontinent to Ghunjerab river, southern part of the Karakoram block which is a part of Eurasian continent. The Kohistan block between these two terranes has relatively higher values of magnetic susceptibility values. Koenigsberger ratio shows that gabbro-norite layering in the Kohistan block might has significant effect of natural remanent magnetization on geomagnetic anomalies. Most of granitic rocks of the block are correlated with ilmenite series showing low magnetic susceptibility while granotoids in northern part of the Kohistan block and Indo-Pakistan subcontinent belong to magnetite series. In the Kohistan block, pre-collisional granites are of magnetite series, while in the case of Indo-Pakistan subcontinent the granitic rocks yielding old age (e.g. $550 \mathrm{Ma}$ ) are of magnetite series and granitic rocks with younger radiometric age correspond to ilmenite series.
\end{abstract}

Keywords: Rock magnetism, Geomagnetic anomaly, Magmatism, Mineralization

\section{Introduction}

Magnetic susceptibility and other rockmagnetic data such as study of natural remanent magnetization (NRM) can provide useful constraint in interpretation of geomagnetic anomalies. In case of granitic rocks, a classification of magnetite series and ilmenite series is given by Ishihara (1977). According to Ishihara's classification, the magnetite series granites are affluent in magnetite which can be easily recognised under microscope, whereas the ilmenite series granites contain little opaque oxide minerals except a small amount of ilmenite. These can be differentiated with the help of magnetic 


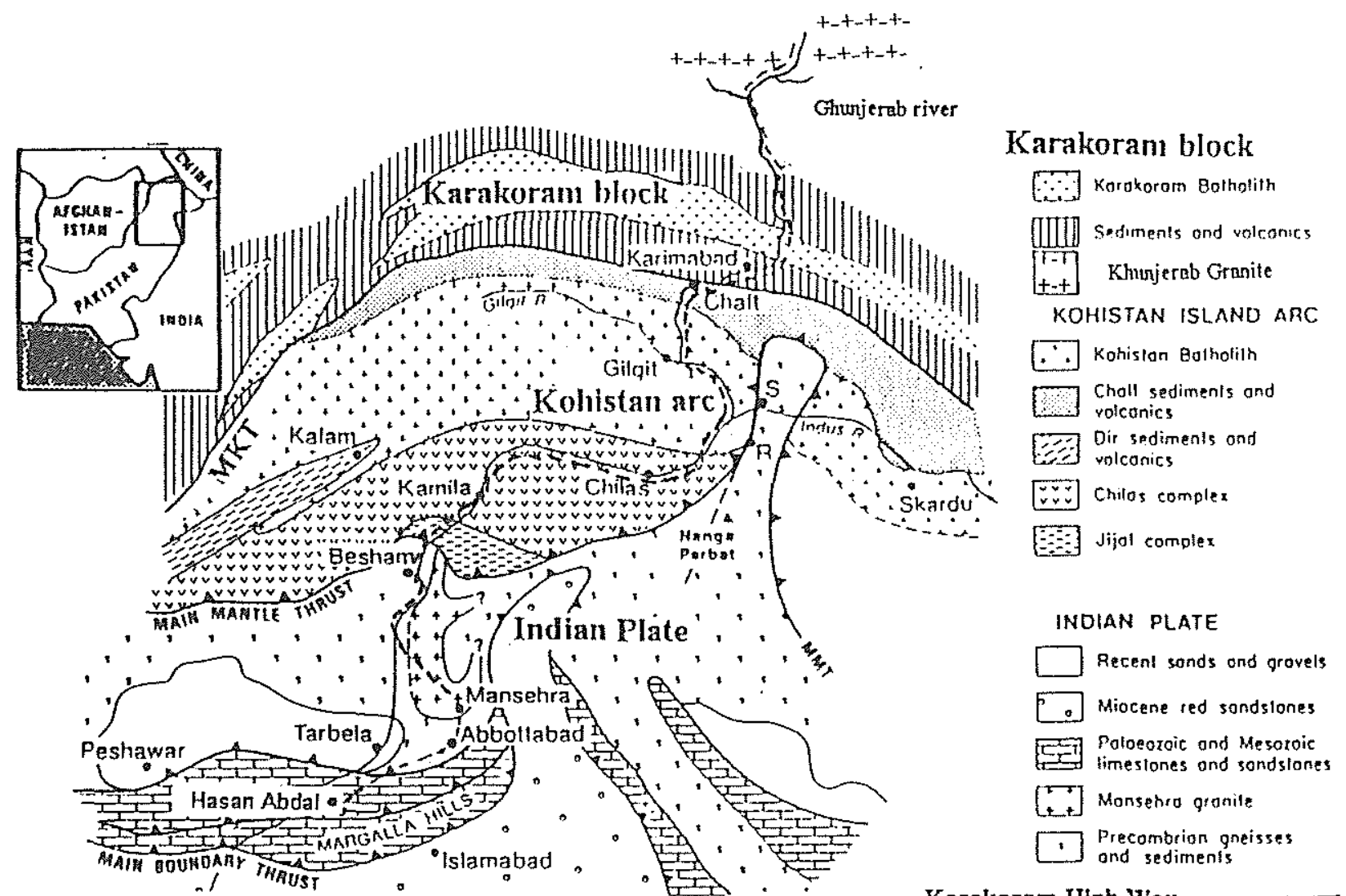

Karakoram High Way - - - -

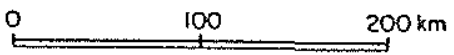

Flgure1. Geological map of Northern Pakistan (Modified after Treloar et al, 1089) 
susceptibility measurement. Magnetite series granites have magnetic susceptibility greater than $10^{-3}$, while ilmenite series granites have very small values less than above mentioned value. Ishihara(1977) pointed reduction state in the generation of the ilmenite series granite magma while oxidation state in magnetite series granite magma, which is also informative for the assessment of magmatism and mineralization potential.

Therefore for these two purposes, (1) to get magnetic susceptibility contrast for geomagnetic survey, (2) for the assessment of magmatism and mineral potential, the variation of magnetic susceptibility was measured along Karakoram Highway (KKH) from Hassan Abdal to Ghunjerab river in northern Pakistan. In this paper magnetic susceptibility variation of different rock units exposed along $\mathrm{KKH}$, Konigsberger ratios of rock units of Kohistan arc, correlation of magnetite and ilmenite series granites with the radiometric ages of different plutons is established and finally the future recommendations for mineral exploration within the granitic rocks of the area are discussed.

\section{Geotectonic Setting}

The northern Pakistan is divided in three different tectonic terranes, IndoPakistan subcontinent (Indian plate), Kohistan arc, Karakoram block (a part of Eurasian continent). There are two major collision zones in the area: the Main Karakoram Thrust (MKT) in the north, between Karakoram block and Kohistan island arc (Figure 1), and in the south, Main Mantle Thrust (MMT) between Kohistan arc and Indian plate (Coward et al., 1986).

Indo-Pakistan subcontinent terrane has Precambrian to Paleozoic metasediments with cover of Mesozoic rocks (Calkin et al., 1975). There are also some granitic rocks dated late Precambrian to early Paleozoic. Treloar et al. (1989) reported three groups of radiometric ages in these granite, i.e. about $550 \mathrm{Ma}, 176-194 \mathrm{Ma}$, and 30-35 Ma. The latter ages relates with tectonic activities, and in particular, the most recent one (30-35 $\mathrm{Ma}$ ) is related with thermal activity after India-Asia collision. On the other hand Karakoram block to the north of MKT comprises metasediments and subduction-related granitic intrusions. According to Jan et al. (1981) granitic rocks of Karakoram block can be divided in two belts: The first is in the north of Karakoram block, there is KhunjerabTrich Mir Belt which is of Cretaceous age and produced at the time of subduction of Paleo-Tethys. Treloar et al. (1989) also reported 107 Ma old plutons from Khunjerab pass. The second is of granitic rock of Karakoram block is Karakoram belt which is the product of subduction of along MKT and MMT during Tertiary.. 

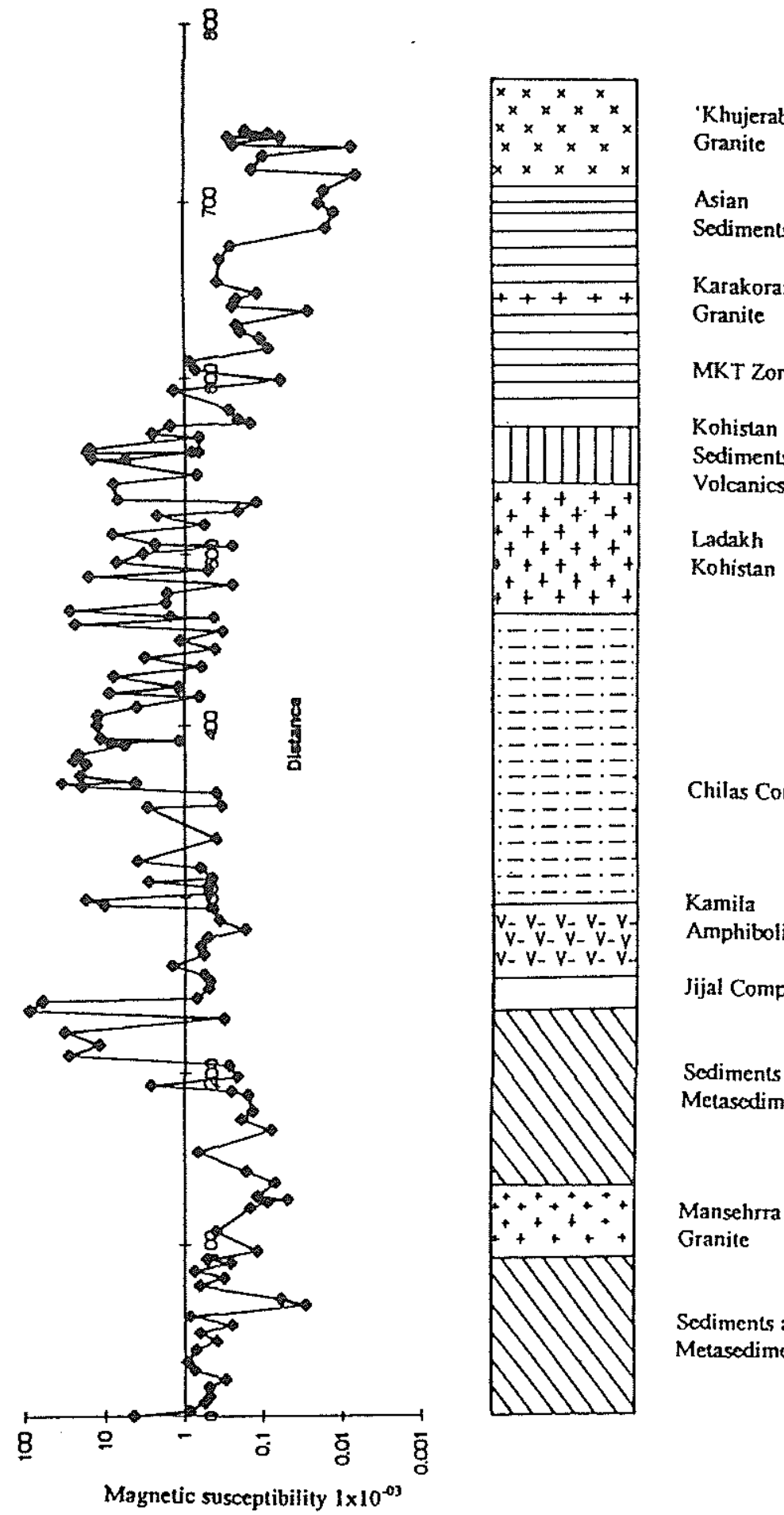

Sediments

Karakoram

宫

$++++$

Granite

‥

$\square$

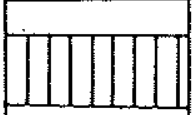

MKT Zone

Kohistan Arc

Sodiments and

$t^{+}+t_{+}^{+}+t^{+}+t$

$\mathrm{B}^{+}+\mathrm{t}_{+}^{+}+{ }_{+}^{+}+$

Volcanics

Ladakh

Kohistan Granite

$\frac{t+t+t}{t+2 t}$

$\because: ニ: ニ:=$

二:二:二:

$=:=:=$

$:=:=$

$::=:=$

$:=:=$

::: : :

$v_{-} v_{-} v_{-} v_{-} v_{-}$

$v-v_{-}-v_{-}-v-v-v$

Kamila $v-v-v-v-v$.

Amphibolites

Jijal Complex

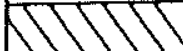

Chilas Complex $\quad$.

昜皇

灵突

04

$+8$

즁

\&.

동

兽

롤

总穿

可

L.

䗆家泀

동

总总

$\checkmark \stackrel{0}{0}$

点密

뭄

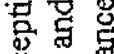

包㖟

क.

옴.

Sodiments and

Metasediments

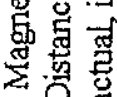

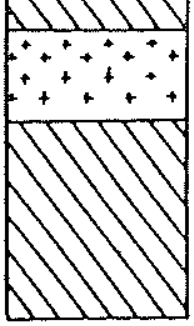

Mansehrra

Granite

总

Sediments and Metasediments 


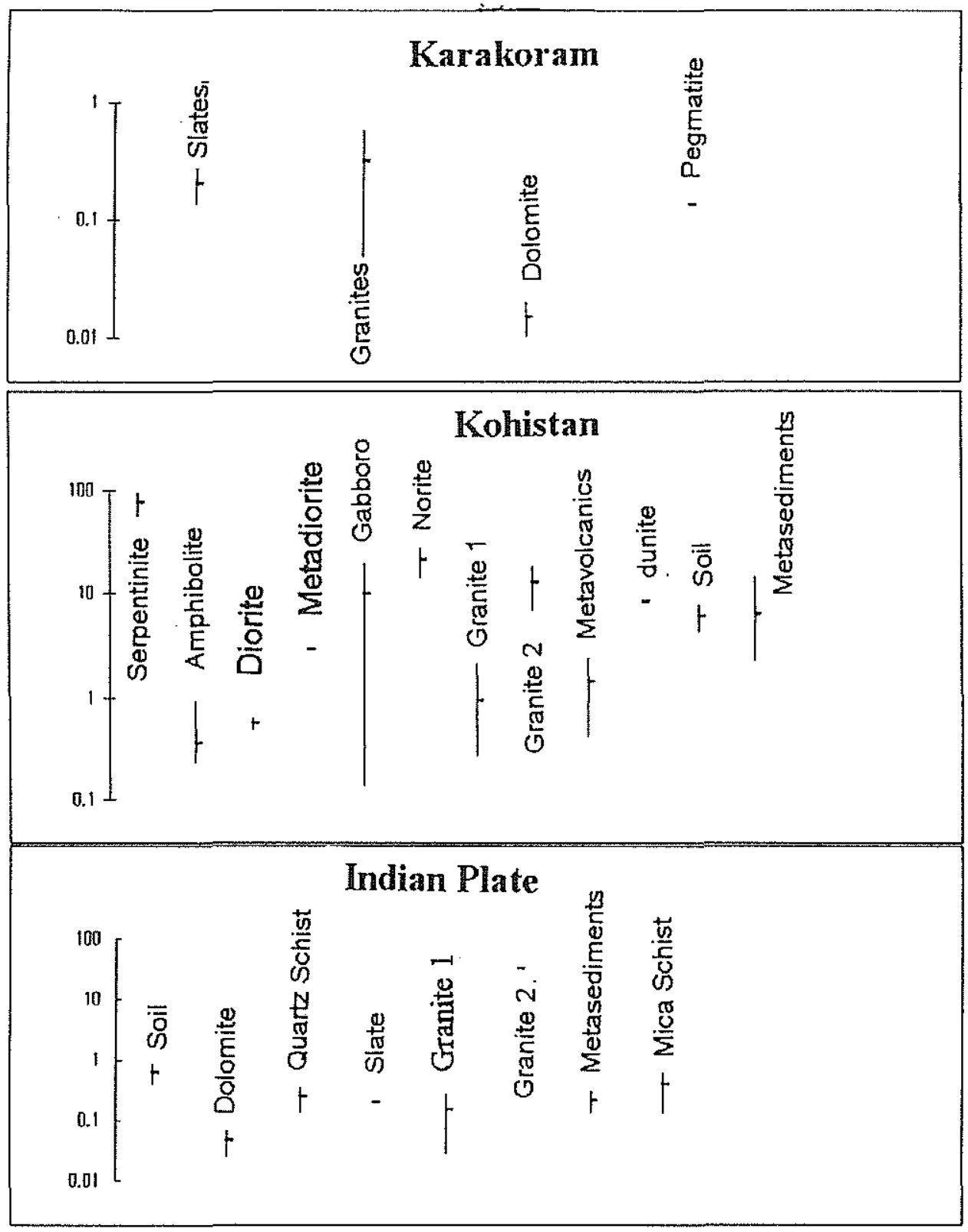

Figure 3. Average Magnetic susceptibility variation of different rock urits in three tectonic terranes of northem Pakistan. Y-axis has magnetic susceptibility values of the order of $10^{-3}$. 
Kohistan terrane was binded between Eurasian continent and Indo-Pakistan subcontinent. Kohistan is considered to be an intra-oceanic arc (Tahirkheli et al., 1980). It is believed that the terrane was partially thrusted under the Karakoram block (Eurasian plate) and obducted on the Indian plate. This terrane preserves cross section from crust/mantle boundary to surface volcanic sedimentary sequence of intra-oceanic arc (Miller et al., 1994).

\section{Results of Magnetic Susceptibility Observation}

Low field magnetic susceptibility observations were made on the exposed in situ rocks from Hassan Abdal to Ghunjerab river along KKH by using the field susceptibility meter, Geofyzika Microkappa KT-5 (measuring frequency $10 \mathrm{kHz}$ ) with sensitivity of $1 \times 10^{-5}$ (SI units). Average value is calculated for each site from twelve observed readings. The distance between each point is three kilometers and special attention was paid to the change in the exposed geologic units. The results of the magnetic susceptibility are shown in Figure 2.

Magnetic susceptibility values are generally low in Indo-Pakistan subcontinent and Karakoram block (Eurasian block), while in the case of Kohistan block the values are higher as compared to above mentioned two terranes. Averaged magnetic susceptibility values for each lithology in the three tectonic blocks are plotted in Figure 3. The maximum magnetic susceptibility is in the serpentinite zone near MMT and lowest values are observed in dolomites of Indian plate and Karakoram plate. There are two sets of magnetic susceptibility values in granitic rocks of Indian plate as well as Kohistan block. One which are less than $1 \times 10^{-3}$ and other those are greater than this value. In both the cases these high susceptibility values are near two collision zones, i.e. MMT and MKT (Figure 2).

\section{(1) Magnetic Susceptibility Variation within Kohistan Terrane}

In this section magnetic susceptibility variations in different geologic divisions of Kohistan terrane is discussed. The Kohistan arc can be divided in four different suits from north to south, Kohistan batholith, Chilas complex, Kamila amphibolite, and Jijal complex (Coward et al., 1986), and upper most part of the arc sequence comprises of metasediments and metavolcanics. Averaged magnetic susceptibility values of different rock units of Kohistan arc are plotted in Figure 4 against a columnar section (modified after Miller et al., 1994). Detailed stratigraphy of the Kohistan arc along with magnetic susceptibility values is discussed below. 


\section{1) Volcanic and Sedimentary Rocks}

The upper part of the arc in the south of MKT comprised of phyllitic slates underlain by metavolcanics formation, the Chalt Volcanics. Both of these units have low values of susceptibilities ranging from 0.21 to $2.54 \times 10^{-3}$ (Figure 4).

\section{2) Kohistan Batholith.}

The Kohistan batholith consists of granites, granodiorites, and diorites. Treloar et al. (1989) reported two types of granitic intrusions on the basis radiometric ages along $\mathrm{KKH}$. One is pre-collisional and the other is post-collisional. (collision of India and Kohistan) granites. The former one is the Matum Das pluton which intruded into the Chalt Volcanics at about $80 \mathrm{Ma}$ (age interpretated by Treloar et al, 1989). This is located in upper part of the arc. The age of post-collisional plutons varies from 54 and $29 \mathrm{Ma}$ (Petterson and Windley, 1985). Magnetic susceptibility values are of two types in the Kohistan batholith. In the upper part of the batholith which is termed as the Matum Das high values are observed from 5.59 to $16.56 \times 10^{-3}$. While in the southern part around Gilgit, lower values (less than $1 \times 10^{-3}$ ) are observed. These high values probably correspond to pre-collisional plutons while low susceptibility values are of later stage plutons.

\section{3) Chilas Complex}

The Chilas complex mainly consists of mafic to ultramafic igneous rocks. The upper part of the complex has diorities which may be roots of Kohistan batholith. In this complex higher values are recorded in dunite and norite. Maximum value is observed in norite at site, which is $24 \times 10^{-3}$. Dunite value is about $8.18 \times 10^{-3}$ while gabbro has less susceptibility as compared to the norite.

\section{4) Kamila Amphibolite}

This unit has various metamorphosed amphibolites intercalated with the Chilas and Jijal complexes. According to Miller et al. (1994), the Kamila amphibolite can be divided in to three parts, upper, middle, and lower. The upper one is intensely metamorphosed, while other two are not so highly metamorphosed. However the magnetic susceptibility values are very low in all parts of the amphibloites and average is about $8 \times 10^{-4}$.

\section{5) Jijal Complex}




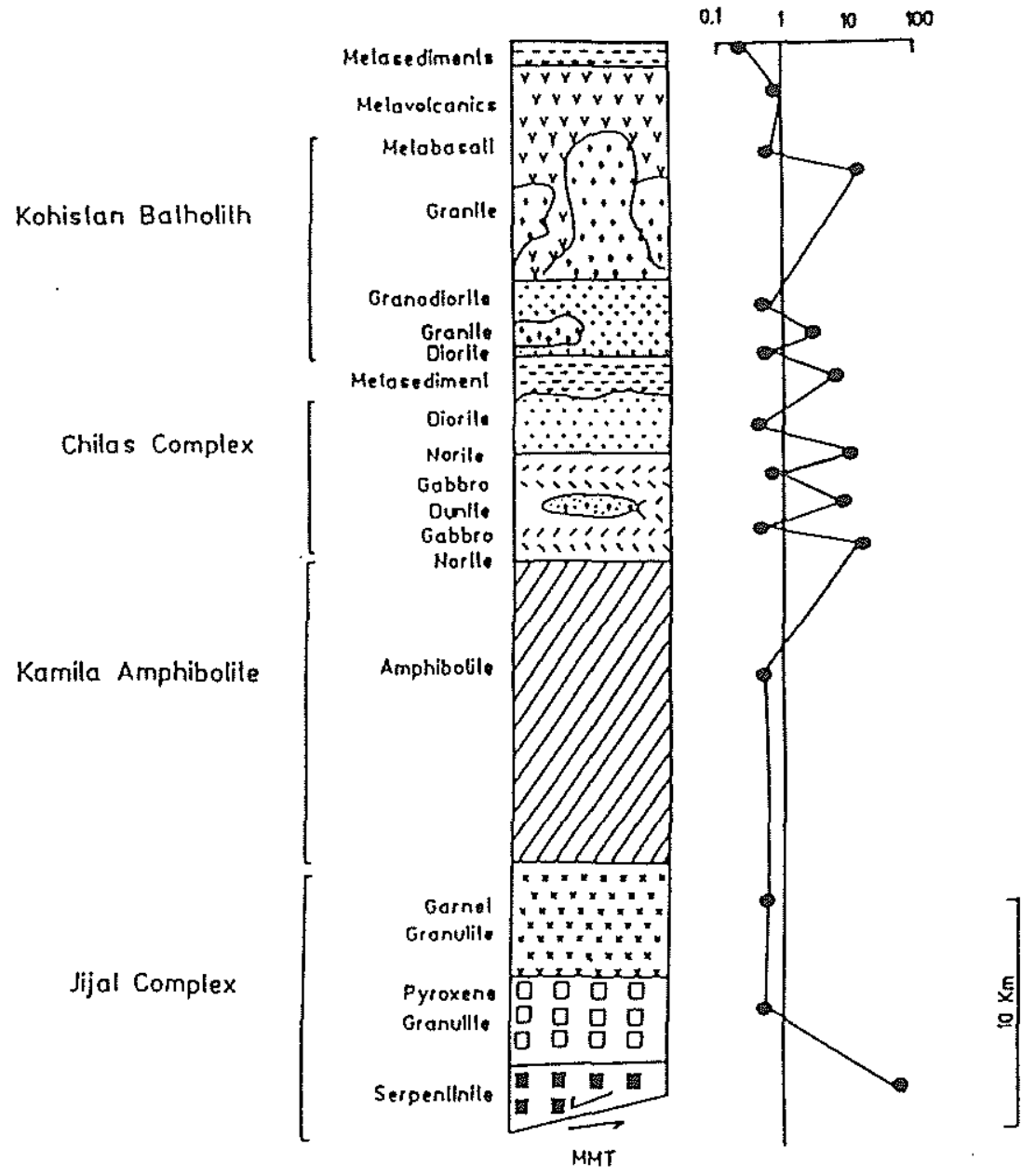

Figure 4: Schematic columnar section of Kohistan island are (modified from Millar et al.,1994) along with average values of suceplibilities of the order $1 \times 10^{-3}$ 
This is the lower most unit of the island arc sequence which has garnet granulite, pyroxene granulite, and serpentinite facies. The bottom of the arc sequence is bounded by MMT, the suture between Indo-Pakistan subcontinent and Kohistan arc. Pyroxene granulite and garnet granulite has low values but serpentinite zone yields more than $8 \times 10^{-2}$

\section{(2) Konigsberger Ratio}

Konigsberger ratio (Qn) is useful to check the effect of natural remanent magnetization (NRM) of different rocks on the geomagnetic anomalies. This is expressed as follows:

$\mathrm{Qn}=\mathrm{Jn} / \mathrm{Ji}=\mathrm{H}_{\mathrm{o}} \mathrm{Jn} / \mathrm{Ji}$

where $\mathrm{Jn}, \mathrm{Ji}, \mathrm{k}$, and $\mathrm{H}_{\mathrm{o}}$ represent $\mathrm{NRM}$ intensity, intensity of induced magnetization under present geomagnetic field, magnetic susceptibility, and present geomagnetic field $(49,000 \mathrm{nT})$. If $\mathrm{Qn}$ is greater than 1 then it can be assumed that remanence of rock may distort geomagnetic anomalies.

This ratio was calculated after measuring remanences of cored samples, the results are compiled in Table 1 . All rock units in the Kohistan terrane has values less than 1.0 except gabbro and norite which has 5.59 and 2.03 , respectively.

Table 1: Koenigsberger ratios for different rock units of Kohistan island arc

\begin{tabular}{|l|l|l|l|}
\hline Sample & Rock Unit & Rock type & Qn \\
\hline KB-31 & Upper most sedimentary & Metasediments & 0.12 \\
\hline KB-30 & Upper most volcanics & Pillow basalt & 0.12 \\
\hline KB-39 & Kohistan batholith & Granite & 0.64 \\
\hline GC-40 & Chilas complex & Gabbro & 5.59 \\
\hline GC-47 & Chilas complex & Norite & 2.03 \\
\hline KAP01 & Kamila amphibolite & Amphibolite & 0.04 \\
\hline DA-09 & Jijal complex & Garnet granulite & 0.83 \\
\hline DA-12 & Jijal complex & Serpentinite & 0.13 \\
\hline
\end{tabular}

\section{Discussion}

(1) Magnetic Susceptibility and Geomagnetic Anomaly 
The magnetic susceptibility values are generally high in the Kohistan terrane as compared to the Indo-Pakistan subcontinent and the Karakoram block (Eurasian continent). This contrast is because of lithologic contrast, i.e. the Kohistan terrane mainly consists of igneous rock bodies which are often composed of mafic to ultra mafic rocks containing iron-bearing minerals. The magnetic susceptibility over MMT is considerably high because of the presence of serpentinite bodies which contain secondary magnetite. This effect of serpentinitization was also observed along MKT in local geomagnetic field survey (Ahmad et al., 1994). Hence it appears that geomagnetic survey can help in order to delineate the sutures. Odintsov et al. (1997) reported low magnetization values in regional satellite data, which is averaged over $1^{\circ} \times 1^{\circ}$ grids over the Himalaya-Karakoram collision zones. This data contrary to local surface survey and susceptibility observation of the rocks shows low magnetizations. This discrepancy can be explained on the basis of high heat flow under the surface. However both local surface survey and satellite data can be successfully used to explore the suture zones in northern Pakistan.

It is always important to note the effect of NRM on geomagnetic anomalies, because this effect might lead to wrong interpretation of the anomalies. The Konigsberger ratio of all rock units of the Kohistan terrane is less than 1.0 except gabbro and norite. Therefore effect of gabbro norite layers of Kohistan should not be ignored while interpreting the magnetic anomalies.

\section{(2) Collision, Age, and Magmatism}

Ishihara (1977) has developed classification of granitic rocks on the basis of magnetic mineralogy. According to this division one class is having high magnetic susceptibility, i.e. magnetite bearing, and other one is of low magnetic susceptibility, i.e. ilmenite bearing. These two classes can be easily differentiate in the field by observing magnetic susceptibility. In our observed profile these both classes are encountered in Indo-Pakistan subcontinent area and Kohistan terrane, while in Karakoram block only ilmenite bearing granites are found. In both the cases of Indo-Pakistan subcontinent and Kohistan terrane magnetite series granites are in the northern parts of the terranes.

Both type of granites in these two terranes show some relationship with the age of granites. In Kohistan terrane magnetite series granites are of pre-collisional plutonic activity about $80 \mathrm{Ma}$ (Treloar et al., 1989), while all other post-collisional plutons are ilmenite series. Though it is not easy to establish such type relationship in the case of Indo-Pakistan subcontinent because of its complex thermal history before and after IndiaAsia collision, high values of magnetic susceptibilty which are encountered in the 
northern part of the Indian plate, which correspond to older granitic rocks about $550 \pm 20$ Ma (Treloar et al., 1989) near Dubair. Some of the other ages from the northern part of Indian continent clustered around 30-35 Ma, 176-194Ma and some are late Cretaceous ages (Treloar et al., 1989). These ages are the record of later thermal history. The first group of ages, 30-35 Ma, are the metamorphic ages of after the Indian collision. The magnetic susceptibility values in these granites near Manshera is low indicating ilmentite series. On the other hand there is no relationship between age and ilmenite/magnetite series granites in Karakoram block. All granites are of ilmenite series.

Table 2: Correlation of age and ilmenite, Magnetite series Granites of northern Pakistan

\begin{tabular}{|l|l|l|l|l|}
\hline Terrane & Rock Unit/Location & Radiometric Age & Reference & $\begin{array}{l}\text { magnetite or } \\
\text { ilmenite series }\end{array}$ \\
\hline Karakoram & Khunjerab & $107 \pm 5 \mathrm{Ma}$ & Treloar et al. (1989) & ilmenite \\
\hline Karakoram & $\begin{array}{l}\text { Karakoram batholith } \\
\text { (near Hunza) }\end{array}$ & $95 \pm 5 \mathrm{Ma}$ & Searl (1991) p 302 & ilmenite \\
\hline Kohistan & Matum Das & $80 \mathrm{Ma}$ & Treloar et al. (1989) & magnetite \\
\hline Kohistan & Pluton around Gilgit & $34 \pm 1 \mathrm{Ma}$ & Treloar et al. (1989) & ilmenite \\
\hline Indian Plate & near MMT & $550 \pm 20 \mathrm{Ma}$ & Treloar et al. (1989) & magnetite \\
\hline Indian Plate & near Manshera & $30-35 \mathrm{Ma}$ & Treloar et al. (1989) & ilmenite \\
\hline
\end{tabular}

\section{(3) Mineralization Potential}

The magnetite-series magmatism often produce sulfide mineralization resources. It is generally believed that magnetite series granites are more promising for different types of ore deposits yielding $\mathrm{Mo}, \mathrm{Cu}, \mathrm{Pb}, \mathrm{Zn}, \mathrm{Ag}$, and $\mathrm{Au}$ (Figure 5). This may be true in the case of terranes in northern Pakistan. Therefore on the basis of this study it can be suggested that more intensive work is required in northern Pakistan especially northern part of Indian plate and northern Kohistan terrane, to differentiate the magnetite series granites of the area by using magnetic susceptibility for the future mineral exploration. 


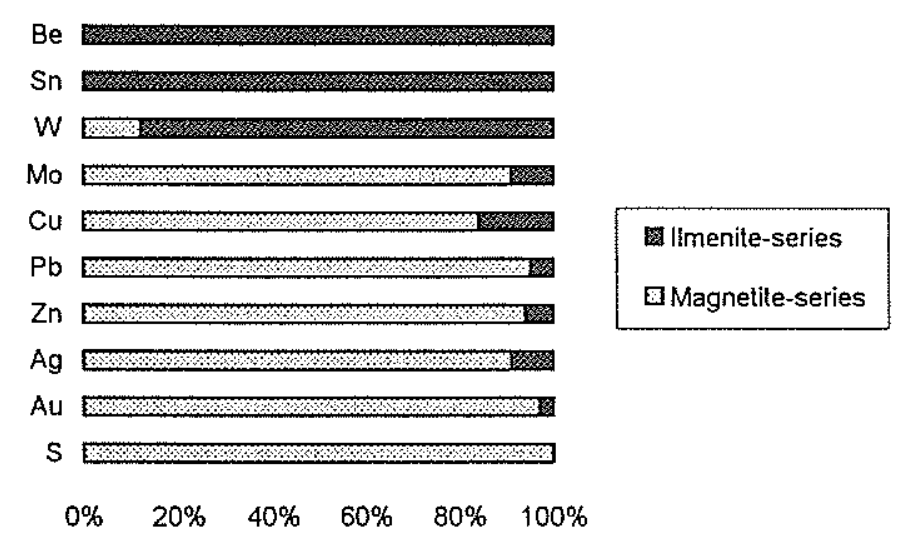

Figure 5: Distribution ratio of elements in ore deposits associating with magnetite series and ilmenite series granic rocks in Japanese island arc (modified from Ishilhara, 1979 in Sasaki et al.,1979, p.29).

\section{Conclusions}

1) Low field magnetic susceptibility is quiet variable along the KKH in northern Pakistan. It is generally high in Kohistan terrane as compared to Indo-Pakistan subcontinent and Karakoram block.

2) According to Konigsberger ratio of different rock units of the Kohistan terrane, gabbro-norite layers of the Chilas complex may effect geomagnetic anomalies.

3) Magnetite series granites are found in northern part of Indo-Pakistan subcontinent and Kohistan terrane. In both the cases the distribution of magnetite series granites and ilmenite granites has relationship with the age of the rocks.

4) Magnetic susceptibility can provide some constraints in order to differentiate the different stages of plutonic activity in northern Pakistan especially in the Kohistan terrane.

5) It is recommended that more attention should be paid in northern part of IndoPakistan terrane as well as Kohistan for future mineral exploration.

Acknowledgements: Thanks are due to Iftikhar Mustafa Khadim and Muhammad Ali of Geoscience Laboratory, Geological Survey of Pakistan, for helping us in field survey. Special thanks are due to S. Hassan Gauhar and Muhammad Sakhawat of Geological Survey of Pakistan, and Junkichi Yajima, Yoshiya Ikeda, Teruo Shirahase, and Shunso Ishihara, Japan International Cooperation Agency (JICA) experts of the Geoscience 
Laboratory Project. A part of this study is financially supported by JICA Geoscience Laboratory Project.

\section{References}

Ahmad, M.N., Yoshida, M., Khadim, I.M., and Kuasar, A.B., 1994, Geomagnetic and VLF-EM survey over northern suture zone and Nomal sulphide mineralized zone, Hunza northern Pakistan. Proc. Geosci. Colloq., Geosci. Lab., Geol. Surv. Pakistan, 8 57-70

Coward, M.P., Windley, B.F., Broughton, R.D., Luff, I.W., Petterson, M.G., Pudsey, C.J., Rex, D.C., and Khan, M.A., 1986, Collision in NW Himalayas, In: Coward, M.P. and Ries, A.C (eds.), Collision Tectonics, Geol. Soc. Spec. Publ., London, 19, 203-219

Calkins, J.A., Offied, T.W., Abdullah, S.K.M and Ali, S.T., 1975,. Geology of Southern Himalaya in Hazara, Pakistan and Adjacent areas. U.S.G.S. Prof. Paper, 716-C, C1-29

Ishihara, S., 1977, The magnetite-series and ilmenite series granitic rocks, Mining Geol, 27, 293-305

Ishihara, S., Yoshida, M. and Seki, Y., 1998, Magnetic susceptibility and sulfur isotopes of granitoids in the northern Pakistan. Chishitsu News (Geology News published by Geological Survey of Japan), 525, 65-75 (in Japanese)

Jan, M. Q., Asif, M., Tazeen, T. and Kamal, M., 1981, Tectonic subdivision of granitic rocks of northern Pakistan, Geol. Bull. Univ. Peshawar, 14, 159-182

Miller, D.J, and Christensen, N.I., 1994, Seismic signature and geochemistry of an Island arc: A multidisciplinary study of the Kohistan accreted terrane, northern Pakistan. J.Geophys.Res., 99, 11623-11642

Odinstov, S.D., Rotanova, N.M. and Odinistov, D.S, 1997, Satellite Magnetic Anomaly Maps over Pakistan and Surrounding Regions: Its Relation to tectonic Structure, in : Paleomagnetism of collision belts, recent progress in geomagnetism, rockmagnetism, and paleomagnetism, Geo. Sci. Lab. Geol. Surv. Pakistan., 1, 85-91

Petterson, M. G. and Windley, B.F, 1985, Rb-Sr dating of Kohistan arc - batholith in the Trans Himalaya of N. Pakistan and its tectonic implications, Earth Planet. Sci. Lett., 74, 45-57,

Sasaki, A., Ishihara, S. and Seki, Y., 1979(eds.), Natural Resources of Earth / Development of Earth's Surface (Earth Science Series No.14). Iwanami Publ., Tokyo, 300p (in Japanese). 
Searle, M.P, 1991, Geology and Tectonics of the Karakoram Mountains, published by John Wiley \& Sons, 358p

Tahirkheli, R.A.K., Mattaur, M., Proust, F. and Tapponier., 1980, The India-Eurasia suture zone in northern Pakistan: Synthesis and interpretation of recent dataat plate scale. In . Farah, A. and Jong, K.A (eds.), Geodynamics of Pakistan, 125130, Geol. Surv. Pakistan, Quetta, 361p

Treloar, P.J., Rex, D.C, Guise, P.G, Coward, M.P, Windley, B.F, Petterson, M.G, Jan, M.Q, Luff, I.W, 1989, K-Ar and Ar-Ar geochronology of Himalayan collision in NW Pakistan: Constraints on the timing of suturing, deformation, metamorphism and uplift, Tectonics, 8, 881-909 